\title{
Monoclonal Antibodies for the Treatment of Cancer
}

\author{
Casey Shuptrine, Rishi Surana, and Louis M. Weiner \\ Lombardi Comprehensive Cancer Center, Georgetown University Medical Center, Washington, \\ DC 20057 \\ Casey Shuptrine: cws39@georgetown.edu; Rishi Surana: rs382@georgetown.edu; Louis M. Weiner: \\ weinerl@georgetown.edu
}

\begin{abstract}
Over the past decade, the clinical utility of monoclonal antibodies has been realized and antibodies are now a mainstay for the treatment of cancer. Antibodies have the unique capacity to target and kill tumor cells while simultaneously activating immune effectors to kill tumor cells through the complement cascade or antibody-dependent cellular cytotoxicity (ADCC). This multifaceted mechanism of action combined with target specificity underlies the capacity of antibodies to elicit anti-tumor responses while minimizing the frequency and magnitude of adverse events. This review will focus on mechanisms of action, clinical applications and putative mechanisms of resistance to monoclonal antibody therapy in the context of cancer.
\end{abstract}

\section{Keywords}

Monoclonal Antibody; Cancer; Immunology; Drug Resistance; Antibody dependent cellular cytotoxicity (ADCC); Complement Dependent Cytotoxicity (CDC); Antibody-like Molecule

\section{Introduction}

The concept of utilizing immunotherapy for the treatment of cancer has been enticing to researchers and clinicians for over a century. Cancer immunotherapy encompasses knowledge gained from a wide range of disciplines and has the potential to procure the 'magic bullet' for the treatment of cancer. The advent of hybridoma technology in 1975 and the development of chimeric, humanized, and human antibodies have increased the availability and utility of immunotherapy for the treatment of cancer [1]. Currently, eleven antibodies are approved for use in oncology, nine of those occurring in the past decade [2]. By targeting tumors through specific or associated antigens, it is possible to selectively eliminate tumor cells and maintain an acceptable toxicity profile. Therapeutic antibodies that target immune cells are also being developed with the goal of breaking local tolerance and stimulating the patient's anti-tumor immune response. As with other treatment modalities, immunotherapy is far from perfect and requires additional study to optimize clinical response and overcome therapeutic resistance. This review will focus on the current state of cancer immunotherapy with the hope of highlighting mechanisms of action, clinical utility, and determinants of resistance of monoclonal antibody therapy.

(C) 2011 Elsevier Ltd. All rights reserved.

Address Correspondence to Louis M. Weiner.

Publisher's Disclaimer: This is a PDF file of an unedited manuscript that has been accepted for publication. As a service to our customers we are providing this early version of the manuscript. The manuscript will undergo copyediting, typesetting, and review of the resulting proof before it is published in its final citable form. Please note that during the production process errors may be discovered which could affect the content, and all legal disclaimers that apply to the journal pertain. 


\section{Structure}

Antibodies, or immunoglobulins (Igs), exist in five separate forms denoted from differences in their constant region, which gives them unique properties and functions. They are $\operatorname{IgA}$, $\operatorname{IgD}$, $\operatorname{IgE}, \operatorname{IgG}$, and $\operatorname{IgM}$, with IgG being the isotype most commonly used in cancer immunotherapy. Antibodies have two antigen binding fragments (Fabs) and one constant fragment $(\mathrm{Fc})$. The $\mathrm{Fab}$ confers antigen specificity via complementarity determining regions (CDRs) while the Fc domain connects IgG antibodies to immune effector mechanisms by engaging Fc $\gamma$ receptors (Fc $\gamma \mathrm{Rs}$ ) on natural killer (NK) cells, neutrophils, monocytes, dendritic cells (DCs) and eosinophils [3]. The $\mathrm{Fc}$ region also binds neonatal $\mathrm{Fc}$ receptors (FcRns), which is thought to protect circulating antibodies from degradation [4].

\section{Mechanisms of action}

Antibodies exert an anti-tumor effect through four mechanisms: perturbation of tumor cell signaling, activation of complement dependent cytotoxicity (CDC), antibody dependent cellular cytotoxicity (ADCC), and induction of adaptive immunity [5].

\subsection{Signaling Perturbation}

Antibodies can be designed to target soluble mediators such as cytokines to inhibit their ability to bind to receptors and induce signaling, or they may target membrane bound receptors, where they can act as agonists or antagonists. Growth factor receptors, such as epidermal growth factor receptor (EGFR), are often overexpressed on tumors and antagonistic antibodies inhibit their ability to mediate mitogenic signaling [6-7]. Likewise, antibodies can inhibit immune suppressing receptors, e.g. CTLA-4, or enhance antigen presentation on APCs through the activation of receptors such as CD40 [8-9]. Of the four subsets of IgG antibodies, IgG2 and IgG4 do not activate CDC or ADCC and are designed primarily for signal perturbation. This often results in fewer immune related adverse events (irEVs) as a consequence of non-specific immune activation [10].

\subsection{Complement Dependent Cytotoxicity (CDC)}

As part of the innate immune system, complement is one of the first mediators of the immune response to pathogens and cells with compromised 'self'. It is a complex proteolytic cascade comprised of over thirty proteins that act to lyse foreign cells through assembly of the membrane attack complex (MAC), stimulate inflammatory processes through anaphylatoxins, and remove opsonized targets [11-12]. When two or more antibodies bind to a cell, the classical complement pathway is activated through the binding of the $\mathrm{C} 1$ complex, a serine protease consisting of $\mathrm{C} 1 \mathrm{q}, \mathrm{C} 1 \mathrm{r}$ and $\mathrm{C} 1 \mathrm{~s}$, to the antibody's $\mathrm{Fc}$ domains. This activates a proteolytic cascade that leads to the formation of the MAC and the release of potent anaphylatoxins and opsonins resulting in cell lysis and phagocytosis [11, 13].

$\mathrm{CDC}$ is an important contributor to the anti-tumor activity of many therapeutic antibodies. Rituximab, a type I chimeric antibody targeting CD20, is approved for treatment of many Bcell malignancies and is a potent activator of CDC. As a type I anti-CD20 antibody, rituximab inhibits internalization and shedding of CD20 and shifts CD20 onto lipid rafts, increasing the likelihood of complement activation through the assembly of rituximabbound receptors [14]. To emphasize this, an in vivo lymphoma model found that loss of C1q abrogated the protective effects of rituximab therapy [15]. The connection between CDC and efficacy of rituximab is also seen clinically where polymorphisms in the C1qA gene in patients with follicular lymphoma are associated with response to rituximab therapy [16]. The importance of CDC to the clinical efficacy of rituximab is not without controversy. There is evidence to suggest that binding of $\mathrm{C} 3 \mathrm{~b}$, an important effector protein in the 
complement cascade, to the cell surface of tumor cells inhibits rituximab mediated ADCC and that inhibition of C3b enhances efficacy of rituximab in vivo [17-18].

Ofatumumab is another type-I anti-CD20 antibody that binds to a distinct epitope of CD20 and induces greater CDC compared to rituximab [19]. Ofatumumab has been reported to bind $\mathrm{Clq}$ with greater avidity than rituximab and efficiently kills rituximab-resistant large B-cell lymphoma cell lines [20]. In addition, ofatumumab is able to lyse cell lines expressing low levels of CD20, which are not efficiently killed by rituximab [21]. In clinical trials, ofatumumab showed high response rates in patients with refractory chronic lymphocytic leukemia (CLL), leading to its approval by the FDA in 2009 [22].

Activation of the complement cascade may be partially responsible for irEVs associated with antibody therapy. One small clinical study found an association with high circulating levels and rapid accumulation of circulating complement components and severe toxicity following rituximab therapy [23].

\subsection{Antibody Dependent Cell-Mediated Cytotoxicity (ADCC)}

The Fc domain of antibodies can activate ADCC through interactions with Fc $\gamma R s$ on effector immune cells. The stimulation of immunoreceptor tyrosine-based activation motifs (ITAMs) and immunoreceptor tyrosine-based inhibitory motifs (ITIMs) results in activating or inhibitory signals through Fc $\gamma$ Rs, respectively. There are three activating Fc $\gamma$ Rs: Fc $\gamma$ RI (CD64), Fc $\gamma$ RIIA (CD32A), and Fc $\gamma$ RIIIA (CD16A) and one inhibitory receptor, Fc $\gamma$ RIIB (CD32B)[24-25]. Natural killer (NK) cells, which predominantly express Fc $\gamma$ RIIIA, are the main effector cells of ADCC, although macrophages and granulocytes cells have been shown to mediate ADCC to a lesser extent [25]. These effector cells, through Fc $\gamma$ Rs, recognize an antibody coated target cell and cause direct lysis of the target cell through release of granzymes and perforin [5]. A seminal study by Clynes et al. showed that the in vivo anti-tumor effect of two clinically useful antibodies, trastuzumab and rituximab, required functional activating Fc $\gamma$ Rs [26]. In addition, animals lacking expression of Fc $\gamma$ RIIB displayed a greater anti-tumor response when treated with therapeutic antibodies [26]. Thus, the balance between expression of activating and inhibitory Fc $\gamma$ Rs may be an important determinant of the clinical efficacy of therapeutic antibodies. In support of this hypothesis, one clinical study showed that the Fc $\gamma$ RIIA polymorphisms Fc $\gamma$ RIIA $131 \mathrm{H} / \mathrm{H}$ and Fc $\gamma$ RIIIA $158 \mathrm{~V} / \mathrm{V}$ are associated with increased response rates to patients with follicular non-Hodgkin's lymphoma (NHL) treated with rituximab [27]. These polymorphisms result in the enhanced affinity of NK cells, monocytes, and granulocytes to the Fc domain of rituximab [25]. These results were further validated in larger clinical studies, which found that the same polymorphisms were independent markers of improved response to rituximab therapy in patients with B-cell non-Hodgkin's lymphoma [28], to cetuximab therapy in patients with metastatic colorectal cancer [29-30], and to trastuzumab therapy in patients with metastatic breast cancer [31].

High levels of macrophages, which can act as an effector for ADCC, are normally a prognostic factor for poor survival but two separate clinical studies have shown that follicular lymphoma patients with high levels of tumor associated macrophages (TAMs) have an improved response to rituximab [32-33]. This enhanced effect of rituximab in patients with increased levels of macrophages is hypothesized, by the two groups, to be due to an increase in ADCC. More studies are required to test this hypothesis and confirm the clinical effects of ADCC on patient outcome. 


\subsection{Induction of Adaptive Immunity}

Several groups have suggested that maximal benefit of antibody therapy is achieved through induction of adaptive immunity. In support of this hypothesis is the amount of time it takes to see clinical benefits of antibody therapy; clinical responses to rituximab were observed six weeks after initiation of treatment [34]. Mechanistically, antibodies can generate adaptive immunity through $\mathrm{CDC}, \mathrm{ADCC}$, or antibody dependent cell-mediated phagocytosis (ADCP). $\mathrm{CDC}$ and ADCC generate tumor cell fragments and release tumor antigens that can be taken up by professional APCs, such as DCs, to initiate tumor directed adaptive immunity. In addition, antibodies can trigger adaptive immunity by acting as an opsonin and triggering Fc dependent phagocytosis of tumor cells by APCs [35]. Tumor antigens are processed by DCs through the endocytic pathway and presented on MHC II to prime CD4+ $\mathrm{T}$ cells. In addition, DCs are capable of presenting engulfed tumor antigens on MHC I molecules to generate tumor-specific CD8+ cytotoxic T-cells (CTLs) in a process called cross presentation [35]. Upon activation, CTLs can directly kill tumor cells that express the cognate peptide loaded on MHC I, or further differentiate into tumor specific memory T cells [36]. Numerous pre-clinical studies support the claim that tumor targeted antibodies can elicit adaptive immune responses, and a growing pool of clinical evidence suggests that this mechanism may contribute to the clinical efficacy of antibodies. DCs loaded with antibody coated ovarian and melanoma cells were able to elicit tumor specific CTLs [37]. Moreover, these CTLs were capable of killing the primary ovarian and melanoma cells [37]. Human DC loaded with myeloma cells coated with anti-syndecan-1 antibodies were able to generate CTLs specific for cancer-testis antigens expressed by the tumor cells [36]. These results were confirmed by a recent study showing that colon cancer cell lines coated with cetuximab, an anti-EGFR antibody, were able to generate tumor specific CTLs from autologous DCs [38]. Blockade of inhibitory Fc $\gamma$ RIIB signaling by selective antibodies enhanced the antigen processing ability of DCs and suggests a potential mechanism of boosting antibody initiated adaptive immunity [39]. Antibody-Fc interactions allow for the processing and presentation of native tumor antigens and may explain why DCs loaded with antibody coated tumor cells elicit stronger CTL responses than DCs loaded with peptide [36]. Induction of adaptive immunity has the potential to create and maintain a sustained anti-tumor immune response in patients. However, the tumor microenvironment is a key determinant of whether this adaptive immune response promotes tolerance or an anti-tumor response [40-41]. Thus, approaches to neutralize tolerogenic factors in the tumor microenvironment are a rational approach to enhance antibody initiated adaptive immunity.

\section{Fc Engineering}

The capacity of antibodies to activate immune effector mechanisms is highly influenced by post-translational modifications of the $\mathrm{Fc}$ domain. Highly fucosylated $\mathrm{Fc}$ domains results in abrogated immune activation, therefore, many groups have engineered antibodies lacking Fc fucosylation [5]. One such non-fucosylated antibody, obinutuzumab (GA101, Genentech), targets CD20 and has shown clinical efficacy, even in patients with rituximab-refractory disease [42]. Obinutuzumab is currently undergoing three phase III clinical trials to evaluate its effectiveness compared to rituximab therapy and in rituximab refractory lymphomas (NCT01332968). Two other anti-CD20 antibodies, AME-133 (LY2469298, Mentrik) and PRO131921 (Genentech), both glycoengineered to lack Fc fucosylation, underwent Phase I/ II clinical trials in B cell NHL [42]. AME-133 recently successfully completed the doseescalating trial while trials involving PRO131921 were terminated.

\section{Antibody-like Molecules}

To further optimize the anti-tumor functions of monoclonal antibodies, numerous antibodylike molecules are in preclinical and clinical trials. These structures adopt certain features of 
antibody structure, but are structurally distinct from traditional monoclonal antibodies. Antibody-like molecules include bispecific antibodies (bsAbs), DARPins, adnectins, diabodies, and tandem scFvs. Bispecific antibodies often lack functional $\mathrm{Fc}$ domains and have two distinct Fab regions and are thus capable of binding two distinct epitopes. Bispecific antibodies that retain functional Fc domains are termed bispecific tri-functional antibodies (triomabs) due to their capability to bind tumor cells and immune cells while maintaining the capacity to mediate Fc dependent effector functions such as CDC and ADCC. This technology has evolved to overcome the suppressive tumor microenvironment, but due to their complexity, widespread development has been cost prohibitive [43].

Catumaxomab is a triomab that targets the tumor antigen EpCAM and the T-cell stimulatory receptor CD3, which allows for direct stimulation of CTLs in the tumor microenvironment[44]. It is currently undergoing numerous phase I, II, and III trials for a variety of EpCam positive tumors and has been shown to enhance survival in patients with malignant ascites [45]. Other triomabs targeting EGFR, HER2, VEGFA, CD64, and CD30 are currently in preclinical and clinical development, [43, 46].

Another type of bsAb are bispecific $\mathrm{T}$ cell engagers (BiTEs), which have two single-chain variable fragments (scFvs) fused together and therefore lack an $\mathrm{Fc}$ domain. Blinatumomab (MT103, Micromet), a BiTE that targets CD19 and CD3, has been successful in clinical trials for B-precursor ALL and NHL [47]. Another BiTE, MT110 (Micromet), targets both EpCAM and CD3 and is currently undergoing a Phase I study for numerous solid tumors (NCT00635596).

Adnectins are antibody mimetics that consist of the type III domain of fibronectin engineered to contain an antigen binding domain. Since adnectins are created from a fibronectin backbone, they are significantly smaller, allowing for a simpler structure and easier manipulation without substituting the affinity or specificity seen with antibodies [48]. CT-322 (Adnexus) is a novel adnectin targeting VEGFR-2, which is important for tumor angiogenesis [49]. It is currently undergoing numerous phase II trials for the treatment of gliomas ( $\underline{\mathrm{NCT} 00562419}$ ), non-small cell lung cancer ( $\underline{\mathrm{NCT} 00850577)}$ ), and NHL (NCT00374179).

\section{Targeting Immune Cells}

\subsection{Regulatory T-cells (Tregs)}

One approach to cancer immunotherapy is to target the effector cells that largely contribute to the immune suppressive tumor microenvironment. CD4+ CD25+ FOXP3+ T cells, also known as regulatory $\mathrm{T}$ cells, transmit inhibitory signals to immune cells [25]. Evidence of their pro-tumor effects is suggested by the association of high Treg content and a negative overall survival in cancer patients [50]. Daclizumab (Zenapax, Roche), a humanized IgG1 mAb targeting CD25 (IL-2R $\alpha$ ), depletes Tregs in patients with metastatic breast cancer when administered with a cancer vaccine [51]. It is currently undergoing phase I/II trials for the treatment of gliomas, breast cancer, melanoma, lymphoma, and leukemia with and without additional vaccines.

Instead of focusing on reducing the quantity of Tregs, another method is to disrupt the potent immune suppressor molecule CTLA-4 that is expressed by Tregs. By inhibiting the functions of CTLA-4, the capacity of Tregs to inhibit the anti-tumor immune response is diminished, resulting in increased levels of CTLs, CD4+ T cells, and APCs [8]. Ipilimumab (Yevroy, Bristol-Myers Squibb), an antagonistic antibody that targets CTLA-4, is effective in activating an anti-tumor immune response and was FDA approved for the treatment of melanoma in early 2011 [52]. In a landmark phase III study, ipilimumab increased the median overall survival of patients with unresectable stage III or IV melanoma from 6.4 
months to 10.1 months [53]. This antibody represents a breakthrough in the treatment of metastatic melanoma, as no promising treatments previously existed. Another anti-CTLA-4 antibody, tremelimumab (CP-675-206, Pfizer) is an IgG2 that is being studied for the treatment of numerous metastatic carcinomas [2]. A phase III trial with tremelimumab for melanoma patients was terminated due to treatment failure, but further analysis determined that a patient subgroup may benefit from tremelimumab treatment ${ }^{48}$. Tremelimumab is also undergoing two phase I trials for prostate (CT00702923), and bladder cancer (NCT00880854) and recently completed a phase II trial for colorectal cancer (

\subsection{CD40}

CD40 is a TNF family receptor whose activation results in release of IL-12 and increased expression of MHC and the co-stimulatory receptor CD86, leading to increased antigen presentation and T cell activation by APCs [10]. CD40 can also be expressed on B-cell malignancies, melanomas, and numerous solid tumors [54]. Ligation of CD40 on tumor cells results in direct cytotoxic effects [55]. As a proinflammatory receptor, CD40 also appears to be vital to the induction of the adaptive immune system [55]. Thus, targeting CD40 can boost anti-tumor immunity and also have a direct cytotoxic effect on tumor cells making it a promising candidate for the treatment of cancer. One CD40 agonist (CP-870.893, Pfizer) was shown to be well tolerated in patients with solid tumors and caused a rapid increase in the percentage of circulating levels of B cells expressing CD86 as well as resulting in one complete and four partial responses [10]. As an IgG2, CP-870.893 does not activate ADCC or CDC, highlighting the efficacy of CD40 ligation in the stimulation of B cells. It is currently undergoing phase I trials for melanoma and advanced pancreatic cancer. Preliminary results show that CP-870.893 in combination with gemcitabine exhibits antitumor activity in patients with pancreatic cancer and pre-clinical data suggests that CP-870.893 may function independent of T-cells [56]. In another phase I trial, the CD40 agonist dacetuzumab (SGN-40, Seattle Genetics), resulted in six patients with B-cell nonHodgkin's lymphoma displaying an objective response and thirteen patients having stable disease [57]. Unlike CP-870.893, dacetuzumab is an IgG1 antibody whose antitumor response is partially attributed to induction of ADCC by NK cells [54]. It is currently undergoing a phase II trial to study its effect on patients with diffuse large B-cell lymphoma when given in conjunction with R-ICE chemotherapy (NCT00529503).

\subsection{Other promising targets}

Many other avenues of targeting immune cells are being evaluated as potential treatments of cancer. CT-011 (CureTech Ltd) is an antagonistic antibody to PD1, whose inhibition can reverse tumor escape from the immune system [58]. It is involved in seven phase II clinical trials for a variety of malignancies. Another target, CD137, has been shown to stimulate CTLs and APCs upon activation [59]. Two CD137 agonists, PF-05082566 (Pfizer) and BMS-663513 (Bristol-Myers Squibb) are currently in a phase I trial for solid tumors and NHL (NCT01307267) and a phase II trial for melanoma (NCT00612664).

\section{Targeting the Tumor Microenvironment}

\subsection{TGF- $\beta$}

As mentioned above, the tumor microenvironment is enriched with factors that inhibit the anti-tumor immune response and promote tumor cell growth. Elevated levels of TGF- $\beta$, which is produced by Tregs and by some tumor cells, serves to potently inhibit CTLs in the tumor microenvironment[41]. GC-1008 is an IgG4 that targets multiple isoforms of TGF- $\beta$ [60]. It is currently in a phase I clinical trial for metastatic renal cell carcinoma or malignant melanoma ( $\underline{\mathrm{NCT} 00356460)}$ ) and a phase II trial for mesothelioma (CT01112293). 


\subsection{Angiogenesis}

Anti-angiogenic antibodies represent a novel method of reducing tumor growth, by preventing vital nutrients from reaching the tumor. Bevacizumab (Avastin; Genentech) is an anti-VEGFA antibody that sequesters VEGFA, preventing it from binding to its receptors [61]. Due to the development of clinical resistance and recent disappointing clinical trials, other ant-angiogenic antibodies have entered clinical trials. Ramucirumab (IMC-1121B, ImClone Systems) is a human IgG1 that blocks VEGFR-2 [62]. It is currently undergoing a phase III clinical trial to compare its utility to docetaxel chemotherapy for HER2-negative metastatic breast cancer (NCT00703326) [62]. Similarly, IMC-18F1 (ImClone Systems) is a human IgG1 that blocks VEGFR-1, and due to promising preclinical data, is being pursued in phase II clinical trials for colorectal and breast cancer [63].

In addition to the VEGF/VEGF-R axis, angiogenesis can be stimulated by platelet-derived growth factor receptors (PDGFRs). IMC-2C5 is an antagonist PDGFR $\beta$ antibody that reduced tumor growth in preclinical models [64]. Other pre-clinical data suggest that targeting PDGFR $\alpha$ may be a more effective anti-cancer strategy than targeting PDGFR $\beta$. IMC-3G3 (ImClone Systems) is an IgG1 that binds to PDGFR $\alpha$ with high affinity, blocking its activation [65]. In a mouse prostate cancer model, treatment with IMC-3G3 reduced the growth of xenografts as well as inhibiting the growth of metastases [66]. Presently, it is undergoing three phase II clinical trials for the treatment of gliomas (NCT00895180), metastatic gastrointestinal stromal tumors (NCT01316263), and prostate cancer (NCT01316263). These antibodies represent a compelling strategy to inhibit angiogenesis and metastasis and will see the most benefit when used in combination with tumor targeted therapy.

\subsection{Cancer Associated Fibroblasts (CAFs)}

CAFs constitute $20-50 \%$ of cells in the microenvironment of various carcinomas [67]. They contribute to tumor initiation, progression and metastasis, but are not themselves transformed [68]. One potential target, fibroblast activating protein (FAP), appears to be present in CAFs but absent in normal fibroblasts [69]. FAP is a type II membrane bound glycoprotein whose blockade inhibits the ability of CAFs to simulate proliferation and invasion [68]. Sibrotuzumab (F19, Boehringer Ingelheim Pharma), is a humanized antibody that targets FAP. It was shown to have a good safety profile with metastatic FAP-positive cancer, resulting in two patients with stable disease and twenty one with progressive disease [67]. Another phase I trial for patients with colorectal cancer was recently completed (NCT00004042). Tenascin, another molecule expressed by CAFs, has been associated with colon cancer metastases [68]. 81C6 is an IgG2 chimeric antibody that acts as an antagonist to tenascin and recently completed a phase II trial for the treatment of metastatic brain cancer $\{$ NCT00002752 $\}$. Results for these studies are expected soon.

\section{Targeting Solid Tumors}

\subsection{EGFR (ErbB1)}

EGFR is overexpressed in many different cancers including colon, head and neck, ovary, lung and malignant gliomas [70]. Signaling via EGFR leads to cell proliferation, migration and invasion primarily via activation of the MAPK and AKT pathways. Cetuximab, the most thoroughly studied anti-EGFR therapeutic antibody, induces cell cycle arrest and apoptosis in tumor cells by blocking ligand binding [71] and receptor dimerization [72]. It has been proposed that cetuximab exerts its in vivo anti-tumor effect in part through induction of ADCC and CDC [73]. However, the clinical relevance of these effector mechanisms in the context of cetuximab therapy is still controversial. Cetuximab has limited impact on progression free survival (PFS) when used as monotherapy for colorectal cancer 
but increases PFS when combined with FOLFIRI chemotherapy [74]. Recent data form the CRYSTAL trial showed that addition of cetuximab increased PFS by 1.5 months and improved median overall survival by 3.5 months compared to FOLFIRI alone in patients harboring wild type KRAS [75].

In addition to cetuximab, panitumumab, a fully human anti-EGFR antibody, is also approved for the treatment of metastatic colorectal cancer. Like cetuximab, panitumumab binds to EGFR and inhibits ligand binding and receptor dimerization [76], however, given its IgG2a isotype, panitumumab is not thought to mediate ADCC. Recent work has challenged this hypothesis by demonstrating that panitumumab is capable of inducing ADCC in vitro using myeloid effector cells [77]. Panitumumab monotherapy is well tolerated [78] and significantly improves PFS in patients with refractory metastatic colorectal cancer [79]. When combined with FOFLOX4 chemotherapy, panitumumab increased PFS in patients with previously untreated, wild-type KRAS metastatic colorectal cancer although no improvement in overall survival was reported [80].

Three new anti-EGFR antibodies are currently being evaluated in phase III studies: necitumumab, zalutumumab, and nimotuzumab. Necitumumab binds to a similar epitope compared with cetuximab [81], is well tolerated [82] and is currently in a phase III study with or without cisplatin and pemetrexed in patients with non-small cell lung cancer (NCT00982111). Zalutumumab, in addition to blocking receptor activation, has been shown to induce ADCC in vitro [77]. Phase III studies in patients with refractory squamous carcinoma of the head and neck showed a modest increase in PFS compared to best supportive care, but with no improvement in overall survival [83]. Nimotuzumab is approved in many countries for the treatment of head and neck cancer and malignant gliomas and is currently being investigated as a treatment for pancreatic [84] and non small cell lung cancer [85]. Unlike other anti-EGFR antibodies, nimotuzumab has not been associated with development of severe adverse events such as aciniform rash [86]. Talavera and colleagues suggest that the absence of rash could be explained by nimotuzumab's unique binding properties: nimotuzumab binds to EGFR with a 10-fold lower affinity compared to cetuximab and panitumumab [87], and allows EGFR to adopt an active confirmation, thereby allowing low levels of ligand-independent signaling through EGFR [86]. This low level of signaling may be enough to maintain survival of normal epithelial cells and avoid toxicities associated with destruction of epithelial tissues [86]. This is in contrast to other anti-EGFR antibodies that promote the inactive conformation of EGFR and thus block signaling through the receptor.

\subsection{HER2 (ErbB2)}

HER 2 is gene amplified and overexpressed in approximately $30 \%$ of breast cancer[88] and overexpressed by some adenocarcinomas of the gastrointestinal tract, lung, ovary and prostate [89]. In contrast to other members of the EGFR family, HER2 has no known ligand and constitutively adopts an open configuration priming it for heterodimerization and increased mitogenic signaling. Currently, trastuzumab is the only FDA approved anti-HER2 antibody. In patients with previously untreated metastatic breast cancer, trastuzumab monotherapy showed a 35\% objective response rate [90]. Trastuzumab's exact mechanisms of action are still unknown, but are thought to include signaling perturbation, inhibition of HER2 shedding, and activation of immune effector mechanisms such as ADCC [91]. Trastuzumab emtansine is a new immunoconjugate in which trastuzumab is conjugated to a derivative of maytansine called DM1. DM1 is a potent anti-mitotic, however, its clinical use is limited by significant toxicity. Trastuzumab-DM1 provides targeted delivery of DM1 and has shown promise in pre-clinical models [92]. Several clinical trials are currently ongoing involving patients with metastatic breast cancer. 
Pertuzumab (Omnitarg), another HER2 directed antibody, is clinically well tolerated [93] and is currently in phase II clinical trials for the treatment of breast and ovarian cancer. Pertuzumab binds to a unique epitope on HER2, but has similar mechanisms of action compared to trastuzumab [94]. Interestingly, unlike trastuzumab, preclinical data suggests that pertuzumab can induce cell death in the absence of HER2 overexpression, possibly by inhibiting ligand-induced HER2 heterodimerization [95-96]; however, no apparent clinical benefit of pertuzumab is seen in patients with HER2 negative metastatic breast cancer [96].

\subsection{HER3 (ErbB3)}

HER3 is overexpressed by certain types of cancers including lung, breast, ovarian and prostate [97]. Although catalytically inactive, HER3 is capable of binding ligand, most notably neuregulin-1, and heterodimerizing with EGFR or HER2 to promote cell proliferation and invasion [97]. MM-121, a fully human IgG2a anti-HER3 antibody, inhibits ligand induced HER3 signaling, HER2-HER3 dimerization, and growth of HER3-expressing xenografts in vivo. MM-121 is currently in phase I clinical trials in patients with advanced solid tumors (NCT00734305).

\subsection{IGF/IGF-R}

Signaling through the insulin-like growth factor receptor (IGF-1R) is reported to play an important role in transformation and cell growth and is overexpressed in a wide range of cancers [98]. Strategies to target IGF-1R and its ligands, IGF-I and IGF-II, using antibodies are being explored in both pre-clinical models and clinical trials. EM164 is a humanized anti-IGF-1R antibody that has been reported to inhibit signaling through IGF-1R in vitro and delays growth of human pancreatic and neuroblastoma xenografts in vivo [98-99].

Dalotuzumab is another humanized IGF-1R antibody that shows anti-tumor efficacy against breast and lung tumor xenografts [100] and is currently in clinical trials for the treatment of breast (NCT01234857), lung (NCT00654420) and colon cancer (NCT00614393). Similarly, MEDI-573, a fully human antibody that neutralizes the IGF-1R ligands IGF-I and IGF-II, has shown anti-tumor efficacy in pre-clinical models [101] and is currently being studied in a phase I clinical trial (NCT00816361).

\section{Combination Approaches}

\subsection{Surgery}

The clinical utility of antibodies in the adjuvant setting is the subject of ongoing investigation. A one year follow up of the Herceptin Adjuvant Trial (HERA) demonstrated that trastuzumab increased disease free survival when given for one year following adjuvant chemotherapy [102] and this benefit persisted four years after initial trastuzumab treatment, although significant crossover between treatment groups was observed [103]. Adding trastuzumab after adjuvant chemotherapy improved survival at two years follow up [104], however, this improvement was lost after four years [103]. Despite the biases and confounding variables in the HERA trial, results of the trial support previously published data on the clinical utility of trastuzumab in the adjuvant setting [105]. In the setting of colorectal cancer, addition of cetuximab to mFOLFLOX6 chemotherapy did not improve outcomes in patients with resected stage III disease [106]. More studies are needed to clearly define the role of tumor targeted antibodies in the adjuvant setting [107].

\subsection{Cytotoxic Chemotherapy}

Cytotoxic chemotherapy has generally been viewed as a modality to induce tumor cell death, with negligible impact on the anti-cancer immune response. However, cell death induced by cytotoxic agents' results in release of tumor antigens and danger signals, which could lead to activation of immune effectors and development of tumor-targeted adaptive 
immunity $[38,108]$. This putative mechanism of synergy between tumor targeted antibodies and cytotoxic chemotherapy could underlie the clinical benefits seen in numerous clinical trials combining antibodies with chemotherapeutic regimens. Addition of trastuzumab to chemotherapy resulted in a higher objective response rate and longer time to disease progression compared to chemotherapy alone in patients with metastatic breast cancer [109]. One preliminary study showed that breast cancer patients who developed anti-HER2 humoral responses after treatment with trastuzumab and chemotherapy had a more favorable outcome compared to patients who failed to develop a humoral response [110]. Similar findings of synergy between cytotoxic chemotherapy and tumor targeted antibodies have been observed using rituximab in patients with non-Hodgkin's lymphoma and using cetuximab in patients with advanced colon cancer [111]. However, adding antibodies to chemotherapeutic regiments is not always beneficial. Recently, a study showed that addition of cetuximab to a regimen of oxaliplatin and capecitabine showed no improvement in progression free survival and overall survival in patients with colorectal cancer, possibly due to the toxicity profile of the oxaliplatin and capecitabine regimen [112].

\subsection{Radiotherapy}

Antibody therapy has also been combined successfully with radiotherapy for the treatment of several cancers. Addition of cetuximab to radiotherapy significantly improved five year survival in patients with squamous cell carcinoma of the head and neck [113]. Recently, Blumenschein and colleagues reported the feasibility of adding cetuximab to a regimen of chemotherapy and radiation in patients with non-small cell lung cancer [114]. Mechanistically, similar to chemotherapy, it has been hypothesized that radiotherapy induces release of danger signals and subsequent activation of the anti-tumor immune response. Clinically, there are numerous reports of elimination of non-irradiated tumor cells at a distant site after local radiotherapy, the so-called "abscopal effect" [115]. Although the mechanism of the abscopal effect is currently unknown, it has been hypothesized that local radiotherapy induces an anti-tumor adaptive immune response that is responsible for eliminating the distant metastases [116]. In addition, ionizing radiation has been shown to increase expression of tumor associated antigens and MHC I leading to enhanced CTL mediated tumor cell killing [117] and potentially enhanced ADCC.

\subsection{Immunomodulators}

Many studies have investigated the rationale of combining immunostimulatory agents with antibody therapy to boost immune effector mechanisms such as ADCC and development of adaptive immunity. IL-2 has been shown to enhance the efficacy of rituximab against nonHodgkin's lymphoma xenografts in pre-clinical models [118]. This enhancement of tumor cell killing was Fc dependent, suggesting that IL-2 enhanced the capacity of rituximab to mediate ADCC or CDC [118]. However, a phase II study found no clinical benefit in adding rIL-2 to rituximab in patients with indolent non-Hodgkin's lymphoma [119]. Similarly, GMCSF is capable of enhancing the capacity of monocytes and macrophages to mediate ADCC and was tested in a phase II study in combination with rituximab in patients with follicular lymphoma. Patients receiving GM-CSF and rituximab showed a high response rate and an increased complete response rate compared to rituximab monotherapy [120]. In addition, patients receiving combination therapy had more circulating monocytes, granulocytes and dendritic cells, although no difference in cell counts was observed between the complete responders and non-complete responders, confounding the link between effector cell recruitment and efficacy [120-121]. Studies are ongoing to evaluate the ability of peptide vaccination in combination with antibody therapy to boost tumor-specific adaptive immune responses. Pre-clinical studies using a HER2 peptide vaccine in combination with an antiHER2 antibody showed generation of HER2 specific T-cells and tumor regression in mice [122]. A phase I/II study showed that combination therapy of HER 2 peptide vaccine with 
trastuzumab was well tolerated and resulted in generation of long lived HER2 specific $T$ cells [123]. Another phase I study showed similar results using a HER2 plasmid-DNA vaccine and trastuzumab [124]. The true impact of combining a tumor targeted antibody with vaccination regimens on survival has yet to be determined but early studies are promising.

\section{Mechanisms of Resistance to Antibody Therapy}

\subsection{Amplification of downstream signaling and alternative signaling pathways}

The most thoroughly described example of a molecular determinant of primary resistance to antibody therapy is KRAS mutational status and sensitivity to the anti-EGFR antibodies cetuximab and panitumumab. Numerous clinical trials have demonstrated that response to cetuximab and panitumumab requires colorectal cancer patients to harbor wild type KRAS. Patients with activating KRAS mutations, most frequently in codons 12 and 13, fail to benefit from anti-EGFR antibody therapy [75, 125-126]. Interestingly, the link between KRAS mutational status and response to anti-EGFR antibodies may not apply to all type of cancers. Initial reports show that KRAS mutational status is not a predictor of clinical response to cetuximab in patients with non-small cell lung cancer [127].

Since KRAS mutations only account for $35-45 \%$ of patients who do not respond to antiEGFR antibody therapy [126], recent studies have focused on the mutational status of BRAF and PIK3CA/PTEN, both of which are activated following engagement of EGFR. Results from the CRYSTAL trial showed that patients harboring V600E BRAF mutations had worse clinical outcomes at all end points [75]. However, due to a small sample size, this trial could not determine the clinical utility of adding cetuximab to FOLFIRI chemotherapy [75]. Indeed, retrospective analysis suggests that BRAF mutations confers resistance to cetuximab therapy, however, definitive prospective studies are needed to confirm this trend [126, 128]. If the trend between BRAF mutations and cetuximab resistance is confirmed, adding a BRAF inhibitor to a regimen of cetuximab and FOLFIRI chemotherapy would be a rational approach to overcome resistance to cetuximab in patients harboring mutated BRAF and wild type KRAS. Vemurafenib, a small molecule inhibitor of mutated BRAF, is currently in clinical trials and has been shown to prolong survival in patients with advanced melanoma [129].

Studies on PIK3CA/PTEN and cetuximab resistance have been conflicting, but suggest that PIK3CA mutations and PTEN loss are associated with resistance to cetuximab [126, 130131]. It has been difficult to directly implicate PIK3CA/PTEN alterations in cetuximab resistance since PIK3CA mutations and PTEN loss/inactivation can co-exist, unlike KRAS and BRAF mutations which are mutually exclusive [126, 132]. In contrast, activating PIK3CA mutations and PTEN loss are thought to be mutually exclusive in breast cancer [133] and mediate resistance to trastuzumab [134-135]. Additionally, PI3K inhibitors reversed trastuzumab resistance mediated by PTEN loss in vitro and patients with trastuzumab resistant breast cancer who were treated with an mTOR inhibitor, which is downstream of PI3K, showed promising clinical responses [136].

IGF-IR has been implicated in resistance to trastuzumab in many pre-clinical studies, as it is capable of heterodimerizing with members of the EGFR family [137-138]. In support of the pre-clinical data, a small study showed that overexpression of IGF-IR correlates with a poor response to trastuzumab plus chemotherapy [139]. Clinical trials evaluating the efficacy of combination therapy of IGF-1R inhibition in the setting of trastuzumab resistance are currently underway (NCT00788333). 


\subsection{Modulation of immune effector mechanisms}

Tumor cells often express immune inhibitory molecules that limit the efficacy of antibody therapy and promote resistance. Pre-clinical data demonstrated that HLA-G, a non-classical MHC molecule, is robustly expressed on human ovarian cancer cell lines and is capable of inhibiting NK mediated lysis in vitro [140]. Similarly, Levy et al. demonstrated that HLA-E, another non-classical MHC molecule, is expressed by primary colon cancer tissue and showed preliminary data suggesting that high HLA-E levels could correlate with shorter disease free survival [141]. Further study revealed that HLA-E expression by colon cancer cell lines inhibited the capacity of cetuximab to mediate ADCC in vitro [142].

Tumors also actively inhibit CDC by expression of membrane bound complement regulatory proteins (mCRPs) such as CD46, CD55, and CD59. mCRPs control the activation of C3 and are expressed by a wide range of cancers including breast, colon, lung and hematological malignancies [143]. Neutralization of mCRPs has been reported to enhance the capability of trastuzumab [144] and rituximab [145] to mediate CDC in vitro. A small study showed that low expression of CD46 and CD55 were associated with response to rituximab. Similarly, CD55 and CD59 expression were correlated with bulky disease in patients with nonHodgkin's lymphoma [146]. This is in contrast to a previous study that showed no correlation between mCRP expression and response to rituximab [147]. Furthermore, there is marked variation in expression of mCRPs in tumor samples and the clinical utility of targeting mCRPs in combination with antibody therapy has not yet been justified using appropriate in vivo models [143].

Impairment of proper antigen presentation is another putative mechanism of resistance to antibody therapy. Tumor cells often down regulate expression of MHC I and as a result evade destruction by MHC-restricted CTLs [148]. A study by Watson and colleagues showed that high MHC I expression, as determined by immunohistochemistry, was associated with longer disease-specific survival (DSS) and that down regulation of MHC I was associated with a worse prognosis in patients with colorectal cancer [149]. Downregulation of MHC may have a clinically relevant impact on the efficacy of antibody therapy given the evidence that therapeutic antibodies can elicit adaptive immune responses [110].

As mentioned above, the tumor microenvironment is heavily infiltrated by Tregs and MDSCs that serve to suppress the anti-cancer immune response. Tregs inhibit anti-tumor immunity by causing apoptosis of immune effectors via perforin and granzymes, by expression of indolamine 2,3 dioxygenase and by production of soluble mediators such as TGF- $\beta$ and IL-10 [150]. In addition to its negative effect on immune effectors, TGF- $\beta$ in the setting of HER 2 amplification and overexpression has been reported to potentiate oncogenic signaling mediated by HER2 and promote resistance to trastuzumab [151]. IL-10 could limit the induction of tumor directed adaptive immunity due to its capacity to downregulate MHC II and B7 expression on antigen presenting cells. MDSCs are capable of recruiting Tregs to the tumor microenvironment and have the capacity to directly inhibit T-cell signaling through nitrosylation of the T-cell receptor [152]. Taken together, cellular and soluble factors in the tumor microenvironment have the capacity to limit the efficacy of antibody therapy by inhibiting immune effectors and promoting oncogenic signaling.

\section{Conclusion}

Monoclonal antibody therapy has revolutionized the treatment of cancer and will continue to be an important treatment modality for cancer in the decades to come. Clinical success of antibody therapy is dependent on understanding the effects of antibody therapy on tumor biology and the anti-cancer immune response. Rational combinations of tumor targeted 
antibodies with other anti-cancer drugs and agents that target the immunosuppressive tumor microenvironment offer the best hope of maximizing the clinical benefit of antibodies.

\section{References}

1. Schreiber RD, Old LJ, Smyth MJ. Cancer Immunoediting: Integrating Immunity's Roles in Cancer Suppression and Promotion. Science. 2011; 331:1565-70. [PubMed: 21436444]

2. Reichert JM. Antibody-based therapeutics to watch in 2011. MAbs. 2011; 3:76-99. [PubMed: 21051951]

3. Weiner LM, Surana R, Wang S. Monoclonal antibodies: versatile platforms for cancer immunotherapy. Nat Rev Immunol. 2010; 10:317-27. [PubMed: 20414205]

4. Roopenian DC, Akilesh S. FcRn: the neonatal Fc receptor comes of age. Nat Rev Immunol. 2007; 7:715-25. [PubMed: 17703228]

5. Kubota T, Niwa R, Satoh M, Akinaga S, Shitara K, Hanai N. Engineered therapeutic antibodies with improved effector functions. Cancer Sci. 2009; 100:1566-72. [PubMed: 19538497]

6. Baselga J, Norton L, Albanell J, Kim YM, Mendelsohn J. Recombinant humanized anti-HER2 antibody (Herceptin) enhances the antitumor activity of paclitaxel and doxorubicin against HER2/ neu overexpressing human breast cancer xenografts. Cancer Res. 1998; 58:2825-31. [PubMed: 9661897]

7. Frampton JE. Cetuximab: A Review of its Use in Squamous Cell Carcinoma of the Head and Neck. Drugs. 2010; 70:1987-2010.10.165/11205010-000000000-00000 [PubMed: 20883055]

8. O’Day SJ, Hamid O, Urba WJ. Targeting cytotoxic T-lymphocyte antigen-4 (CTLA-4). Cancer. 2007; 110:2614-27. [PubMed: 18000991]

9. French RR, Chan HTC, Tutt AL, Glennie MJ. CD40 antibody evokes a cytotoxic T-cell response that eradicates lymphoma and bypasses T-cell help. Nat Med. 1999; 5:548-53. [PubMed: 10229232]

10. Khalil M, Vonderheide RH. Anti-CD40 agonist antibodies: Preclinical and clinical experience. Update on Cancer Therapeutics. 2007; 2:61-5. [PubMed: 19587842]

11. Dunkelberger JR, Song WC. Complement and its role in innate and adaptive immune responses. Cell Res. 2010; 20:34-50. [PubMed: 20010915]

12. Zipfel PF, Skerka C. Complement regulators and inhibitory proteins. Nat Rev Immunol. 2009; 9:729-40. [PubMed: 19730437]

13. Stoermer KA, Morrison TE. Complement and viral pathogenesis. Virology. 2011; 411:362-73. [PubMed: 21292294]

14. Winiarska M, Glodkowska-Mrowka E, Jacek B, Golab J. Molecular Mechanisms of the Antitumor Effects of Anti-CD20 Antibodies. Frontiers in Bioscience. 2011; 16:277-306. [PubMed: 21196171]

15. Di Gaetano N, Cittera E, Nota R, Vecchi A, Grieco V, Scanziani E, et al. Complement Activation Determines the Therapeutic Activity of Rituximab In Vivo. The Journal of Immunology. 2003; 171:1581-7. [PubMed: 12874252]

16. Racila E, Link BK, Weng W-K, Witzig TE, Ansell S, Maurer MJ, et al. A Polymorphism in the Complement Component C1qA Correlates with Prolonged Response Following Rituximab Therapy of Follicular Lymphoma. Clinical Cancer Research. 2008; 14:6697-703. [PubMed: 18927313]

17. Wang SY, Racila E, Taylor RP, Weiner GJ. NK-cell activation and antibody-dependent cellular cytotoxicity induced by rituximab-coated target cells is inhibited by the $\mathrm{C} 3 \mathrm{~b}$ component of complement. Blood. 2008; 111:1456-63. [PubMed: 18024795]

18. Wang SY, Veeramani S, Racila E, Cagley J, Fritzinger DC, Vogel CW, et al. Depletion of the C3 component of complement enhances the ability of rituximab-coated target cells to activate human NK cells and improves the efficacy of monoclonal antibody therapy in an in vivo model. Blood. 2009; 114:5322-30. [PubMed: 19805620]

19. Teeling JL, Mackus WJ, Wiegman LJ, van den Brakel JH, Beers SA, French RR, et al. The biological activity of human CD20 monoclonal antibodies is linked to unique epitopes on CD20. J Immunol. 2006; 177:362-71. [PubMed: 16785532] 
20. Cheson BD. Ofatumumab, a novel anti-CD20 monoclonal antibody for the treatment of B-cell malignancies. J Clin Oncol. 2010; 28:3525-30. [PubMed: 20458041]

21. Teeling JL, French RR, Cragg MS, van den Brakel J, Pluyter M, Huang H, et al. Characterization of new human CD20 monoclonal antibodies with potent cytolytic activity against non-Hodgkin lymphomas. Blood. 2004; 104:1793-800. [PubMed: 15172969]

22. Coiffier B, Lepretre S, Pedersen LM, Gadeberg O, Fredriksen H, van Oers MH, et al. Safety and efficacy of ofatumumab, a fully human monoclonal anti-CD20 antibody, in patients with relapsed or refractory B-cell chronic lymphocytic leukemia: a phase 1-2 study. Blood. 2008; 111:1094100. [PubMed: 18003886]

23. Van Der Kolk LE, Grillo-López AJ, Baars JW, Hack CE, Van Oers MHJ. Complement activation plays a key role in the side-effects of rituximab treatment. British Journal of Haematology. 2001; 115:807-11. [PubMed: 11843813]

24. Nimmerjahn F, Ravetch JV. Fcgamma receptors: old friends and new family members. Immunity. 2006; 24:19-28. [PubMed: 16413920]

25. Ferris RL, Jaffee EM, Ferrone S. Tumor antigen-targeted, monoclonal antibody-based immunotherapy: clinical response, cellular immunity, and immunoescape. J Clin Oncol. 2010; 28:4390-9. [PubMed: 20697078]

26. Clynes RA, Towers TL, Presta LG, Ravetch JV. Inhibitory Fc receptors modulate in vivo cytoxicity against tumor targets. Nat Med. 2000; 6:443-6. [PubMed: 10742152]

27. Cartron G, Dacheux L, Salles G, Solal-Celigny P, Bardos P, Colombat P, et al. Therapeutic activity of humanized anti-CD20 monoclonal antibody and polymorphism in $\mathrm{IgG}$ Fc receptor FcgammaRIIIa gene. Blood. 2002; 99:754-8. [PubMed: 11806974]

28. Weng WK, Levy R. Two immunoglobulin G fragment $\mathrm{C}$ receptor polymorphisms independently predict response to rituximab in patients with follicular lymphoma. J Clin Oncol. 2003; 21:3940-7. [PubMed: 12975461]

29. Bibeau F, Lopez-Crapez E, Di Fiore F, Thezenas S, Ychou M, Blanchard F, et al. Impact of Fc \{gamma\}RIIa-Fc \{gamma\}RIIIa polymorphisms and KRAS mutations on the clinical outcome of patients with metastatic colorectal cancer treated with cetuximab plus irinotecan. J Clin Oncol. 2009; 27:1122-9. [PubMed: 19164213]

30. Zhang W, Gordon M, Schultheis AM, Yang DY, Nagashima F, Azuma M, et al. FCGR2A and FCGR3A polymorphisms associated with clinical outcome of epidermal growth factor receptor expressing metastatic colorectal cancer patients treated with single-agent cetuximab. J Clin Oncol. 2007; 25:3712-8. [PubMed: 17704420]

31. Musolino A, Naldi N, Bortesi B, Pezzuolo D, Capelletti M, Missale G, et al. Immunoglobulin G fragment $\mathrm{C}$ receptor polymorphisms and clinical efficacy of trastuzumab-based therapy in patients with HER-2/neu-positive metastatic breast cancer. J Clin Oncol. 2008; 26:1789-96. [PubMed: 18347005]

32. Taskinen M, Karjalainen-Lindsberg M-L, Nyman H, Eerola L-M, Leppä S. A High TumorAssociated Macrophage Content Predicts Favorable Outcome in Follicular Lymphoma Patients Treated with Rituximab and Cyclophosphamide-Doxorubicin-Vincristine-Prednisone. Clinical Cancer Research. 2007; 13:5784-9. [PubMed: 17908969]

33. Canioni D, Salles G, Mounier N, Brousse N, Keuppens M, Morchhauser F, et al. High Numbers of Tumor-Associated Macrophages Have an Adverse Prognostic Value That Can Be Circumvented by Rituximab in Patients With Follicular Lymphoma Enrolled Onto the GELA-GOELAMS FL-2000 Trial. Journal of Clinical Oncology. 2008; 26:440-6. [PubMed: 18086798]

34. Hainsworth JD, Litchy S, Burris HA, Scullin DC, Corso SW, Yardley DA, et al. Rituximab as First-Line and Maintenance Therapy for Patients With Indolent Non-Hodgkin's Lymphoma. Journal of Clinical Oncology. 2002; 20:4261-7. [PubMed: 12377971]

35. Albert ML, Sauter B, Bhardwaj N. Dendritic cells acquire antigen from apoptotic cells and induce class I-restricted CTLs. Nature. 1998; 392:86-9. [PubMed: 9510252]

36. Dhodapkar KM, Krasovsky J, Williamson B, Dhodapkar MV. Antitumor monoclonal antibodies enhance cross-presentation of cellular antigens and the generation of myeloma-specific killer $\mathrm{T}$ cells by dendritic cells. J Exp Med. 2002; 195:125-33. [PubMed: 11781371] 
37. Cioca DP, Deak E, Cioca F, Paunescu V. Monoclonal antibodies targeted against melanoma and ovarian tumors enhance dendritic cell-mediated cross-presentation of tumor-associated antigens and efficiently cross-prime CD8+ T cells. J Immunother. 2006; 29:41-52. [PubMed: 16365599]

38. Correale P, Botta C, Cusi M, Del Vecchio M, De Santi M, Gori Savellini G, et al. Cetuximab +/chemotherapy enhances dendritic cell-mediated phagocytosis of colon cancer cells and ignites a highly efficient colon cancer antigen-specific cytotoxic T-cell response in vitro. Int J Cancer. 2011

39. Dhodapkar KM, Kaufman JL, Ehlers M, Banerjee DK, Bonvini E, Koenig S, et al. Selective blockade of inhibitory Fcgamma receptor enables human dendritic cell maturation with IL-12p70 production and immunity to antibody-coated tumor cells. Proc Natl Acad Sci U S A. 2005; 102:2910-5. [PubMed: 15703291]

40. Peng Y, Martin DA, Kenkel J, Zhang K, Ogden CA, Elkon KB. Innate and adaptive immune response to apoptotic cells. Journal of Autoimmunity. 2007; 29:303-9. [PubMed: 17888627]

41. Rabinovich GA, Gabrilovich D, Sotomayor EM. Immunosuppressive Strategies that are Mediated by Tumor Cells. Annual Review of Immunology. 2007; 25:267-96.

42. Alduaij W, Illidge TM. The future of anti-CD20 monoclonal antibodies: are we making progress? Blood. 2011; 117:2993-3001. [PubMed: 21209380]

43. Chames P, Baty D. Bispecific antibodies for cancer therapy: The light at the end of the tunnel? MAbs. 2009; 1:539-47. [PubMed: 20073127]

44. Linke R, Klein A, Seimetz D. Catumaxomab: Clinical Development and Future Directions. MAbs. 2010; 2:129-36. [PubMed: 20190561]

45. Parsons SMP, Koralewski P, Kutarska E, Kolesnik OO, Ströhlein MA. Intraperitoneal treatment of malignant ascites due to epithelial tumors with catumaxomab: A phase II/III study. Journal of Clinical Oncology. 2008

46. Bostrom J, Yu S-F, Kan D, Appleton BA, Lee CV, Billeci K, et al. Variants of the Antibody Herceptin That Interact with HER2 and VEGF at the Antigen Binding Site. Science. 2009; 323:1610-4. [PubMed: 19299620]

47. Beck A, Wurch T, Bailly C, Corvaia N. Strategies and challenges for the next generation of therapeutic antibodies. Nat Rev Immunol. 2010; 10:345-52. [PubMed: 20414207]

48. Lipovsek D. Adnectins: engineered target-binding protein therapeutics. Protein Eng Des Sel. 2011; 24:3-9. [PubMed: 21068165]

49. Mamluk R, Carvajal IM, Morse BA, Wong H, Abramowitz J, Aslanian S, et al. Anti-tumor effect of CT-322 as an adnectin inhibitor of vascular endothelial growth factor receptor-2. MAbs. 2010:2.

50. Menetrier-Caux C, Gobert M, Caux C. Differences in Tumor Regulatory T-Cell Localization and Activation Status Impact Patient Outcome. Cancer Research. 2009; 69:7895-8. [PubMed: 19808962]

51. Rech AJ, Vonderheide RH. Clinical Use of Anti-CD25 Antibody Daclizumab to Enhance Immune Responses to Tumor Antigen Vaccination by Targeting Regulatory T cells. Annals of the New York Academy of Sciences. 2009; 1174:99-106. [PubMed: 19769742]

52. Di Giacomo A, Danielli R, Guidoboni M, Calabrò L, Carlucci D, Miracco C, et al. Therapeutic efficacy of ipilimumab, an anti-CTLA-4 monoclonal antibody, in patients with metastatic melanoma unresponsive to prior systemic treatments: clinical and immunological evidence from three patient cases. Cancer Immunology, Immunotherapy. 2009; 58:1297-306.

53. Hodi FS, O’Day SJ, McDermott DF, Weber RW, Sosman JA, Haanen JB, et al. Improved Survival with Ipilimumab in Patients with Metastatic Melanoma. New England Journal of Medicine. 2010; 363:711-23. [PubMed: 20525992]

54. Oflazoglu E, Stone IJ, Brown L, Gordon KA, van Rooijen N, Jonas M, et al. Macrophages and Fcreceptor interactions contribute to the antitumour activities of the anti-CD40 antibody SGN-40. Br J Cancer. 2008; 100:113-7. [PubMed: 19066610]

55. Elgueta R, Benson MJ, De Vries VC, Wasiuk A, Guo Y, Noelle RJ. Molecular mechanism and function of CD40/CD40L engagement in the immune system. Immunological Reviews. 2009; 229:152-72. [PubMed: 19426221] 
56. Beatty GL, Chiorean EG, Fishman MP, Saboury B, Teitelbaum UR, Sun W, et al. CD40 agonists alter tumor stroma and show efficacy against pancreatic carcinoma in mice and humans. Science. 2011; 331:1612-6. [PubMed: 21436454]

57. Advani R, Forero-Torres A, Furman RR, Rosenblatt JD, Younes A, Ren H, et al. Phase I Study of the Humanized Anti-CD40 Monoclonal Antibody Dacetuzumab in Refractory or Recurrent NonHodgkin's Lymphoma. Journal of Clinical Oncology. 2009; 27:4371-7. [PubMed: 19636010]

58. Rosenblatt J, Glotzbecker B, Mills H, Vasir B, Tzachanis D, Levine JD, et al. PD-1 Blockade by CT-011, Anti-PD-1 Antibody, Enhances Ex Vivo T-cell Responses to Autologous Dendritic Cell/ Myeloma Fusion Vaccine. Journal of Immunotherapy. 2011; 34:409-18.10.1097/CJI. 0b013e31821ca6ce [PubMed: 21577144]

59. Melero I, Hervas-Stubbs S, Glennie M, Pardoll DM, Chen L. Immunostimulatory monoclonal antibodies for cancer therapy. Nat Rev Cancer. 2007; 7:95-106. [PubMed: 17251916]

60. Grutter C, Wilkinson T, Turner R, Podichetty S, Finch D, McCourt M, et al. A cytokineneutralizing antibody as a structural mimetic of 2 receptor interactions. Proceedings of the National Academy of Sciences. 2008; 105:20251-6.

61. Ohm JE, Gabrilovich DI, Sempowski GD, Kisseleva E, Parman KS, Nadaf S, et al. VEGF inhibits $\mathrm{T}$ cell development and may contribute to tumor-induced immune suppression. Blood. 2003

62. Mackey J, Gelmon K, Martin M, McCarthy N, Pinter T, Rupin M, et al. TRIO-012: a multicenter, multinational, randomized, double-blind phase III study of IMC-1121B plus docetaxel versus placebo plus docetaxel in previously untreated patients with HER2-negative, unresectable, locally recurrent or metastatic breast cancer. Clin Breast Cancer. 2009; 9:258-61. [PubMed: 19933083]

63. Schwartz JD, Rowinsky EK, Youssoufian H, Pytowski B, Wu Y. Vascular endothelial growth factor receptor-1 in human cancer: concise review and rationale for development of IMC-18F1 (Human antibody targeting vascular endothelial growth factor receptor-1). Cancer. 2010; 116:1027-32. [PubMed: 20127948]

64. Shen J, Vil MD, Prewett M, Damoci C, Zhang H, Li H, et al. Development of a fully human antiPDGFRbeta antibody that suppresses growth of human tumor xenografts and enhances antitumor activity of an anti-VEGFR2 antibody. Neoplasia. 2009; 11:594-604. [PubMed: 19484148]

65. Hecht JR, Mitchell E, Chidiac T, Scroggin C, Hagenstad C, Spigel D, et al. A randomized phase IIIB trial of chemotherapy, bevacizumab, and panitumumab compared with chemotherapy and bevacizumab alone for metastatic colorectal cancer. J Clin Oncol. 2009; 27:672-80. [PubMed: 19114685]

66. Russell MR, Liu Q, Fatatis A. Targeting the alpha Receptor for Platelet-Derived Growth Factor as a Primary or Combination Therapy in a Preclinical Model of Prostate Cancer Skeletal Metastasis. Clinical Cancer Research. 2010; 16:5002-10. [PubMed: 20813817]

67. Scott AM, Wiseman G, Welt S, Adjei A, Lee F-T, Hopkins W, et al. A Phase I Dose-Escalation Study of Sibrotuzumab in Patients with Advanced or Metastatic Fibroblast Activation Proteinpositive Cancer. Clinical Cancer Research. 2003; 9:1639-47. [PubMed: 12738716]

68. Xing F, Saidou J, Watabe K. Cancer Associated Fibroblasts (CAFs) in tumor microenvironment. Frontiers in Bioscience. 2010; 15:166-79. [PubMed: 20036813]

69. Zhang Y, Tang H, Cai J, Zhang T, Guo J, Feng D, et al. Ovarian cancer-associated fibroblasts contribute to epithelial ovarian carcinoma metastasis by promoting angiogenesis, lymphangiogenesis and tumor cell invasion. Cancer Letters. 2011; 303:47-55. [PubMed: 21310528]

70. Zhang Z, Stiegler AL, Boggon TJ, Kobayashi S, Halmos B. EGFR-mutated lung cancer: a paradigm of molecular oncology. Oncotarget. 2010; 1:497-514. [PubMed: 21165163]

71. Li S, Schmitz KR, Jeffrey PD, Wiltzius JJ, Kussie P, Ferguson KM. Structural basis for inhibition of the epidermal growth factor receptor by cetuximab. Cancer Cell. 2005; 7:301-11. [PubMed: 15837620]

72. Patel D, Bassi R, Hooper A, Prewett M, Hicklin DJ, Kang X. Anti-epidermal growth factor receptor monoclonal antibody cetuximab inhibits EGFR/HER-2 heterodimerization and activation. Int J Oncol. 2009; 34:25-32. [PubMed: 19082474] 
73. Hsu YF, Ajona D, Corrales L, Lopez-Picazo JM, Gurpide A, Montuenga LM, et al. Complement activation mediates cetuximab inhibition of non-small cell lung cancer tumor growth in vivo. Mol Cancer. 2010; 9:139. [PubMed: 20529262]

74. Van Cutsem E, Kohne CH, Hitre E, Zaluski J, Chang Chien CR, Makhson A, et al. Cetuximab and chemotherapy as initial treatment for metastatic colorectal cancer. N Engl J Med. 2009; 360:140817. [PubMed: 19339720]

75. Van Cutsem E, Kohne CH, Lang I, Folprecht G, Nowacki MP, Cascinu S, et al. Cetuximab Plus Irinotecan, Fluorouracil, and Leucovorin As First-Line Treatment for Metastatic Colorectal Cancer: Updated Analysis of Overall Survival According to Tumor KRAS and BRAF Mutation Status. J Clin Oncol. 2011; 29:2011-9. [PubMed: 21502544]

76. Dubois EA, Cohen AF. Panitumumab. Br J Clin Pharmacol. 2009; 68:482-3. [PubMed: 19843050]

77. Schneider-Merck T, Lammerts van Bueren JJ, Berger S, Rossen K, van Berkel PH, Derer S, et al. Human IgG2 antibodies against epidermal growth factor receptor effectively trigger antibodydependent cellular cytotoxicity but, in contrast to $\mathrm{IgG} 1$, only by cells of myeloid lineage. $\mathrm{J}$ Immunol. 2010; 184:512-20. [PubMed: 19949082]

78. Weiner LM, Belldegrun AS, Crawford J, Tolcher AW, Lockbaum P, Arends RH, et al. Dose and schedule study of panitumumab monotherapy in patients with advanced solid malignancies. Clin Cancer Res. 2008; 14:502-8. [PubMed: 18223225]

79. Van Cutsem E, Peeters M, Siena S, Humblet Y, Hendlisz A, Neyns B, et al. Open-label phase III trial of panitumumab plus best supportive care compared with best supportive care alone in patients with chemotherapy-refractory metastatic colorectal cancer. J Clin Oncol. 2007; 25:165864. [PubMed: 17470858]

80. Douillard JY, Siena S, Cassidy J, Tabernero J, Burkes R, Barugel M, et al. Randomized, phase III trial of panitumumab with infusional fluorouracil, leucovorin, and oxaliplatin (FOLFOX4) versus FOLFOX4 alone as first-line treatment in patients with previously untreated metastatic colorectal cancer: the PRIME study. J Clin Oncol. 2010; 28:4697-705. [PubMed: 20921465]

81. Li S, Kussie P, Ferguson KM. Structural basis for EGF receptor inhibition by the therapeutic antibody IMC-11F8. Structure. 2008; 16:216-27. [PubMed: 18275813]

82. Kuenen B, Witteveen PO, Ruijter R, Giaccone G, Dontabhaktuni A, Fox F, et al. A Phase I Pharmacologic Study of Necitumumab (IMC-11F8), a Fully Human IgG1 Monoclonal Antibody Directed Against EGFR in Patients with Advanced Solid Malignancies. Clin Cancer Res. 2010

83. Machiels JP, Subramanian S, Ruzsa A, Repassy G, Lifirenko I, Flygare A, et al. Zalutumumab plus best supportive care versus best supportive care alone in patients with recurrent or metastatic squamous-cell carcinoma of the head and neck after failure of platinum-based chemotherapy: an open-label, randomised phase 3 trial. Lancet Oncol. 2011; 12:333-43. [PubMed: 21377930]

84. Strumberg D, Schultheis B, Scheulen ME, Hilger RA, Krauss J, Marschner N, et al. Phase II study of nimotuzumab, a humanized monoclonal anti-epidermal growth factor receptor (EGFR) antibody, in patients with locally advanced or metastatic pancreatic cancer. Invest New Drugs. 2010

85. Bebb G, Smith C, Rorke S, Boland W, Nicacio L, Sukhoo R, et al. Phase I clinical trial of the antiEGFR monoclonal antibody nimotuzumab with concurrent external thoracic radiotherapy in Canadian patients diagnosed with stage IIb, III or IV non-small cell lung cancer unsuitable for radical therapy. Cancer Chemother Pharmacol. 2011; 67:837-45. [PubMed: 20563810]

86. Talavera A, Friemann R, Gomez-Puerta S, Martinez-Fleites C, Garrido G, Rabasa A, et al. Nimotuzumab, an antitumor antibody that targets the epidermal growth factor receptor, blocks ligand binding while permitting the active receptor conformation. Cancer Res. 2009; 69:5851-9. [PubMed: 19584289]

87. Boland $\mathrm{W}$, Bebb G. The emerging role of nimotuzumab in the treatment of non-small cell lung cancer. Biologics. 2010; 4:289-98. [PubMed: 21116327]

88. Slamon DJ, Godolphin W, Jones LA, Holt JA, Wong SG, Keith DE, et al. Studies of the HER-2/ neu proto-oncogene in human breast and ovarian cancer. Science. 1989; 244:707-12. [PubMed: 2470152]

89. Chen JS, Lan K, Hung MC. Strategies to target HER2/neu overexpression for cancer therapy. Drug Resist Updat. 2003; 6:129-36. [PubMed: 12860460] 
90. Vogel CL, Cobleigh MA, Tripathy D, Gutheil JC, Harris LN, Fehrenbacher L, et al. Efficacy and safety of trastuzumab as a single agent in first-line treatment of HER2-overexpressing metastatic breast cancer. J Clin Oncol. 2002; 20:719-26. [PubMed: 11821453]

91. Hudis CA. Trastuzumab--mechanism of action and use in clinical practice. N Engl J Med. 2007; 357:39-51. [PubMed: 17611206]

92. Junttila TT, Li G, Parsons K, Phillips GL, Sliwkowski MX. Trastuzumab-DM1 (T-DM1) retains all the mechanisms of action of trastuzumab and efficiently inhibits growth of lapatinib insensitive breast cancer. Breast Cancer Res Treat. 2010

93. Agus DB, Gordon MS, Taylor C, Natale RB, Karlan B, Mendelson DS, et al. Phase I clinical study of pertuzumab, a novel HER dimerization inhibitor, in patients with advanced cancer. J Clin Oncol. 2005; 23:2534-43. [PubMed: 15699478]

94. Franklin MC, Carey KD, Vajdos FF, Leahy DJ, de Vos AM, Sliwkowski MX. Insights into ErbB signaling from the structure of the ErbB2-pertuzumab complex. Cancer Cell. 2004; 5:317-28. [PubMed: 15093539]

95. Agus DB, Akita RW, Fox WD, Lewis GD, Higgins B, Pisacane PI, et al. Targeting ligandactivated ErbB2 signaling inhibits breast and prostate tumor growth. Cancer Cell. 2002; 2:127-37. [PubMed: 12204533]

96. Gianni L, Llado A, Bianchi G, Cortes J, Kellokumpu-Lehtinen PL, Cameron DA, et al. Open-label, phase II, multicenter, randomized study of the efficacy and safety of two dose levels of Pertuzumab, a human epidermal growth factor receptor 2 dimerization inhibitor, in patients with human epidermal growth factor receptor 2-negative metastatic breast cancer. J Clin Oncol. 2010; 28:1131-7. [PubMed: 20124183]

97. Soler M, Mancini F, Meca-Cortes O, Sanchez-Cid L, Rubio N, Lopez-Fernandez S, et al. HER3 is required for the maintenance of neuregulin-dependent and -independent attributes of malignant progression in prostate cancer cells. Int J Cancer. 2009; 125:2565-75. [PubMed: 19530240]

98. Maloney EK, McLaughlin JL, Dagdigian NE, Garrett LM, Connors KM, Zhou XM, et al. An antiinsulin-like growth factor I receptor antibody that is a potent inhibitor of cancer cell proliferation. Cancer Res. 2003; 63:5073-83. [PubMed: 12941837]

99. Geoerger B, Brasme JF, Daudigeos-Dubus E, Opolon P, Venot C, Debussche L, et al. Anti-insulinlike growth factor 1 receptor antibody EM164 (murine AVE1642) exhibits anti-tumour activity alone and in combination with temozolomide against neuroblastoma. Eur J Cancer. 2010; 46:3251-62. [PubMed: 20591650]

100. Goetsch L, Gonzalez A, Leger O, Beck A, Pauwels PJ, Haeuw JF, et al. A recombinant humanized anti-insulin-like growth factor receptor type I antibody (h7C10) enhances the antitumor activity of vinorelbine and anti-epidermal growth factor receptor therapy against human cancer xenografts. Int J Cancer. 2005; 113:316-28. [PubMed: 15386423]

101. Gao J, Chesebrough JW, Cartlidge SA, Ricketts SA, Incognito L, Veldman-Jones M, et al. Dual IGF-I/II-neutralizing antibody MEDI-573 potently inhibits IGF signaling and tumor growth. Cancer Res. 2011; 71:1029-40. [PubMed: 21245093]

102. Piccart-Gebhart MJ, Procter M, Leyland-Jones B, Goldhirsch A, Untch M, Smith I, et al. Trastuzumab after adjuvant chemotherapy in HER2-positive breast cancer. N Eng1 J Med. 2005; 353:1659-72. [PubMed: 16236737]

103. Gianni L, Dafni U, Gelber RD, Azambuja E, Muehlbauer S, Goldhirsch A, et al. Treatment with trastuzumab for 1 year after adjuvant chemotherapy in patients with HER2-positive early breast cancer: a 4-year follow-up of a randomised controlled trial. Lancet Oncol. 2011; 12:236-44. [PubMed: 21354370]

104. Smith I, Procter M, Gelber RD, Guillaume S, Feyereislova A, Dowsett M, et al. 2-year follow-up of trastuzumab after adjuvant chemotherapy in HER2-positive breast cancer: a randomised controlled trial. Lancet. 2007; 369:29-36. [PubMed: 17208639]

105. Romond EH, Perez EA, Bryant J, Suman VJ, Geyer CE Jr, Davidson NE, et al. Trastuzumab plus adjuvant chemotherapy for operable HER2-positive breast cancer. N Engl J Med. 2005; 353:1673-84. [PubMed: 16236738]

106. Van Loon K, Venook AP. Adjuvant treatment of colon cancer: what is next? Curr Opin Oncol. 2011; 23:403-9. [PubMed: 21537178] 
107. Murray JC, Wu CS, Weiner LM. Why Cetuximab is Not Active in the Adjuvant Setting. Curr Colorectal Cancer Rep. 201110.1007/s11888-011-0103-4

108. Haynes NM, van der Most RG, Lake RA, Smyth MJ. Immunogenic anti-cancer chemotherapy as an emerging concept. Curr Opin Immunol. 2008; 20:545-57. [PubMed: 18573339]

109. Slamon DJ, Leyland-Jones B, Shak S, Fuchs H, Paton V, Bajamonde A, et al. Use of chemotherapy plus a monoclonal antibody against HER2 for metastatic breast cancer that overexpresses HER2. N Eng1 J Med. 2001; 344:783-92. [PubMed: 11248153]

110. Taylor C, Hershman D, Shah N, Suciu-Foca N, Petrylak DP, Taub R, et al. Augmented HER-2 specific immunity during treatment with trastuzumab and chemotherapy. Clin Cancer Res. 2007; 13:5133-43. [PubMed: 17785568]

111. Coiffier B. Rituximab in combination with CHOP improves survival in elderly patients with aggressive non-Hodgkin's lymphoma. Semin Oncol. 2002; 29:18-22. [PubMed: 12040530]

112. Maughan TS, Adams RA, Smith CG, Meade AM, Seymour MT, Wilson RH, et al. Addition of cetuximab to oxaliplatin-based first-line combination chemotherapy for treatment of advanced colorectal cancer: results of the randomised phase 3 MRC COIN trial. Lancet. 2011

113. Bonner JA, Harari PM, Giralt J, Cohen RB, Jones CU, Sur RK, et al. Radiotherapy plus cetuximab for locoregionally advanced head and neck cancer: 5-year survival data from a phase 3 randomised trial, and relation between cetuximab-induced rash and survival. Lancet Oncol. 2010; 11:21-8. [PubMed: 19897418]

114. Blumenschein GR Jr, Paulus R, Curran WJ, Robert F, Fossella F, Werner-Wasik M, et al. Phase II Study of Cetuximab in Combination With Chemoradiation in Patients With Stage IIIA/B NonSmall-Cell Lung Cancer: RTOG 0324. J Clin Oncol. 2011

115. Okuma K, Yamashita H, Niibe Y, Hayakawa K, Nakagawa K. Abscopal effect of radiation on lung metastases of hepatocellular carcinoma: a case report. J Med Case Reports. 2011; 5:111. [PubMed: 21418591]

116. Ma Y, Kepp O, Ghiringhelli F, Apetoh L, Aymeric L, Locher C, et al. Chemotherapy and radiotherapy: cryptic anticancer vaccines. Semin Immunol. 2010; 22:113-24. [PubMed: 20403709]

117. Garnett CT, Palena C, Chakraborty M, Tsang KY, Schlom J, Hodge JW. Sublethal irradiation of human tumor cells modulates phenotype resulting in enhanced killing by cytotoxic $\mathrm{T}$ lymphocytes. Cancer Res. 2004; 64:7985-94. [PubMed: 15520206]

118. Lopes de Menezes DE, Denis-Mize K, Tang Y, Ye H, Kunich JC, Garrett EN, et al. Recombinant interleukin-2 significantly augments activity of rituximab in human tumor xenograft models of B-cell non-Hodgkin lymphoma. J Immunother. 2007; 30:64-74. [PubMed: 17198084]

119. Khan KD, Emmanouilides C, Benson DM Jr, Hurst D, Garcia P, Michelson G, et al. A phase 2 study of rituximab in combination with recombinant interleukin-2 for rituximab-refractory indolent non-Hodgkin's lymphoma. Clin Cancer Res. 2006; 12:7046-53. [PubMed: 17145827]

120. Cartron G, Zhao-Yang L, Baudard M, Kanouni T, Rouille V, Quittet P, et al. Granulocytemacrophage colony-stimulating factor potentiates rituximab in patients with relapsed follicular lymphoma: results of a phase II study. J Clin Oncol. 2008; 26:2725-31. [PubMed: 18427151]

121. Juweid ME, Weiner GJ, Link BK, Horning SJ, Wiseman GA. Measuring granulocyte and monocyte accumulation at malignant lymphoma sites. J Clin Oncol. 2009; 27:154-5. [PubMed: 19029411]

122. Orlandi F, Guevara-Patino JA, Merghoub T, Wolchok JD, Houghton AN, Gregor PD. Combination of epitope-optimized DNA vaccination and passive infusion of monoclonal antibody against HER2/neu leads to breast tumor regression in mice. Vaccine. 2011; 29:3646-54. [PubMed: 21435405]

123. Disis ML, Wallace DR, Gooley TA, Dang Y, Slota M, Lu H, et al. Concurrent trastuzumab and HER2/neu-specific vaccination in patients with metastatic breast cancer. J Clin Oncol. 2009; 27:4685-92. [PubMed: 19720923]

124. Norell H, Poschke I, Charo J, Wei WZ, Erskine C, Piechocki MP, et al. Vaccination with a plasmid DNA encoding HER-2/neu together with low doses of GM-CSF and IL-2 in patients with metastatic breast carcinoma: a pilot clinical trial. J Transl Med. 2010; 8:53. [PubMed: 20529245] 
125. Amado RG, Wolf M, Peeters M, Van Cutsem E, Siena S, Freeman DJ, et al. Wild-type KRAS is required for panitumumab efficacy in patients with metastatic colorectal cancer. J Clin Oncol. 2008; 26:1626-34. [PubMed: 18316791]

126. Bardelli A, Siena S. Molecular mechanisms of resistance to cetuximab and panitumumab in colorectal cancer. J Clin Oncol. 2010; 28:1254-61. [PubMed: 20100961]

127. Gatzemeier U, von Pawel J, Vynnychenko I, Zatloukal P, de Marinis F, Eberhardt WE, et al. First-cycle rash and survival in patients with advanced non-small-cell lung cancer receiving cetuximab in combination with first-line chemotherapy: a subgroup analysis of data from the FLEX phase 3 study. Lancet Oncol. 2011; 12:30-7. [PubMed: 21169060]

128. Colucci G, Giuliani F, Garufi C, Mattioli R, Manzione L, Russo A, et al. Cetuximab plus FOLFOX-4 in Untreated Patients with Advanced Colorectal Cancer: A Gruppo Oncologico dell'Italia Meridionale Multicenter Phase II Study. Oncology. 2010; 79:415-22. [PubMed: 21474966]

129. Chapman PB, Hauschild A, Robert C, Haanen JB, Ascierto P, Larkin J, et al. Improved Survival with Vemurafenib in Melanoma with BRAF V600E Mutation. N Engl J Med. 2011

130. Sartore-Bianchi A, Martini M, Molinari F, Veronese S, Nichelatti M, Artale S, et al. PIK3CA mutations in colorectal cancer are associated with clinical resistance to EGFR-targeted monoclonal antibodies. Cancer Res. 2009; 69:1851-7. [PubMed: 19223544]

131. Loupakis F, Pollina L, Stasi I, Ruzzo A, Scartozzi M, Santini D, et al. PTEN expression and KRAS mutations on primary tumors and metastases in the prediction of benefit from cetuximab plus irinotecan for patients with metastatic colorectal cancer. J Clin Oncol. 2009; 27:2622-9. [PubMed: 19398573]

132. Spindler KL, Pallisgaard N, Lindebjerg J, Frifeldt SK, Jakobsen A. EGFR related mutational status and association to clinical outcome of third-line cetuximab-irinotecan in metastatic colorectal cancer. BMC Cancer. 2011; 11:107. [PubMed: 21439039]

133. Saal LH, Holm K, Maurer M, Memeo L, Su T, Wang X, et al. PIK3CA mutations correlate with hormone receptors, node metastasis, and ERBB2, and are mutually exclusive with PTEN loss in human breast carcinoma. Cancer Res. 2005; 65:2554-9. [PubMed: 15805248]

134. Berns K, Horlings HM, Hennessy BT, Madiredjo M, Hijmans EM, Beelen K, et al. A functional genetic approach identifies the PI3K pathway as a major determinant of trastuzumab resistance in breast cancer. Cancer Cell. 2007; 12:395-402. [PubMed: 17936563]

135. Nagata Y, Lan KH, Zhou X, Tan M, Esteva FJ, Sahin AA, et al. PTEN activation contributes to tumor inhibition by trastuzumab, and loss of PTEN predicts trastuzumab resistance in patients. Cancer Cell. 2004; 6:117-27. [PubMed: 15324695]

136. Andre F, Campone M, O’Regan R, Manlius C, Massacesi C, Sahmoud T, et al. Phase I study of everolimus plus weekly paclitaxel and trastuzumab in patients with metastatic breast cancer pretreated with trastuzumab. J Clin Oncol. 2010; 28:5110-5. [PubMed: 20975068]

137. Lu Y, Zi X, Zhao Y, Mascarenhas D, Pollak M. Insulin-like growth factor-I receptor signaling and resistance to trastuzumab (Herceptin). J Natl Cancer Inst. 2001; 93:1852-7. [PubMed: 11752009]

138. Huang X, Gao L, Wang S, McManaman JL, Thor AD, Yang X, et al. Heterotrimerization of the growth factor receptors erbB2, erbB3, and insulin-like growth factor-i receptor in breast cancer cells resistant to herceptin. Cancer Res. 2010; 70:1204-14. [PubMed: 20103628]

139. Garrett JT, Arteaga CL. Resistance to HER2-directed antibodies and tyrosine kinase inhibitors: Mechanisms and clinical implications. Cancer Biol Ther. 2011; 11:793-800. [PubMed: 21307659]

140. Lin A, Yan WH, Xu HH, Gan MF, Cai JF, Zhu M, et al. HLA-G expression in human ovarian carcinoma counteracts NK cell function. Ann Oncol. 2007; 18:1804-9. [PubMed: 17846022]

141. Levy EM, Bianchini M, Von Euw EM, Barrio MM, Bravo AI, Furman D, et al. Human leukocyte antigen-E protein is overexpressed in primary human colorectal cancer. Int J Oncol. 2008; 32:633-41. [PubMed: 18292941]

142. Levy EM, Sycz G, Arriaga JM, Barrio MM, von Euw EM, Morales SB, et al. Cetuximabmediated cellular cytotoxicity is inhibited by HLA-E membrane expression in colon cancer cells. Innate Immun. 2009; 15:91-100. [PubMed: 19318419] 
143. Fishelson Z, Donin N, Zell S, Schultz S, Kirschfink M. Obstacles to cancer immunotherapy: expression of membrane complement regulatory proteins (mCRPs) in tumors. Mol Immunol. 2003; 40:109-23. [PubMed: 12914817]

144. Jurianz K, Maslak S, Garcia-Schuler H, Fishelson Z, Kirschfink M. Neutralization of complement regulatory proteins augments lysis of breast carcinoma cells targeted with rhumAb anti-HER2. Immunopharmacology. 1999; 42:209-18. [PubMed: 10408382]

145. You T, Hu W, Ge X, Shen J, Qin X. Application of a novel inhibitor of human CD59 for the enhancement of complement-dependent cytolysis on cancer cells. Cell Mol Immunol. 2011; 8:157-63. [PubMed: 21258360]

146. Dzietczenia J, Wrobel T, Mazur G, Poreba R, Jazwiec B, Kuliczkowski K. Expression of complement regulatory proteins: CD46, CD55, and CD59 and response to rituximab in patients with CD20+ non-Hodgkin's lymphoma. Med Oncol. 2010; 27:743-6. [PubMed: 19662541]

147. Weng WK, Levy R. Expression of complement inhibitors CD46, CD55, and CD59 on tumor cells does not predict clinical outcome after rituximab treatment in follicular non-Hodgkin lymphoma. Blood. 2001; 98:1352-7. [PubMed: 11520782]

148. Algarra I, Garcia-Lora A, Cabrera T, Ruiz-Cabello F, Garrido F. The selection of tumor variants with altered expression of classical and nonclassical MHC class I molecules: implications for tumor immune escape. Cancer Immunol Immunother. 2004; 53:904-10. [PubMed: 15069585]

149. Watson NF, Ramage JM, Madjd Z, Spendlove I, Ellis IO, Scholefield JH, et al. Immunosurveillance is active in colorectal cancer as downregulation but not complete loss of MHC class I expression correlates with a poor prognosis. Int J Cancer. 2006; 118:6-10. [PubMed: 16003753]

150. Zou W. Regulatory T cells, tumour immunity and immunotherapy. Nat Rev Immunol. 2006; 6:295-307. [PubMed: 16557261]

151. Wang SE. The Functional Crosstalk between HER2 Tyrosine Kinase and TGF-beta Signaling in Breast Cancer Malignancy. J Signal Transduct. 2011; 2011:804236. [PubMed: 21637380]

152. Nagaraj S, Gupta K, Pisarev V, Kinarsky L, Sherman S, Kang L, et al. Altered recognition of antigen is a mechanism of CD8+ T cell tolerance in cancer. Nat Med. 2007; 13:828-35. [PubMed: 17603493] 

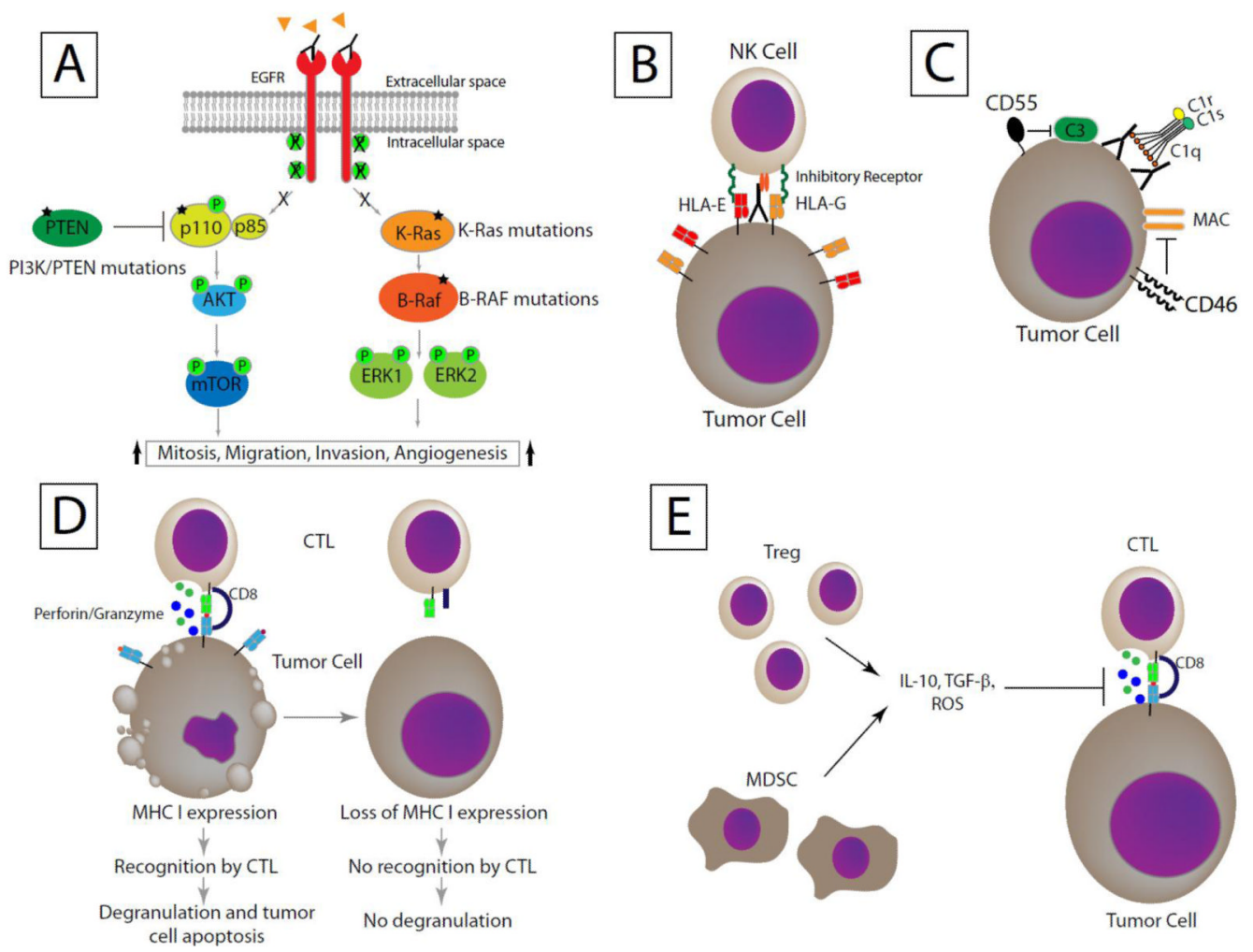

Figure 1. Proposed mechanisms of resistance to antibody therapy

The most thoroughly characterized mechanism of resistance to antibody therapy is amplification of downstream signaling. In the case of EGFR, resistance to anti-EGFR antibodies can be mediated by mutations (stars) in K-Ras, B-Raf, or PI3K/PTEN that allow tumor cells to bypass receptor activation to activate pro-survival genes (A). Tumor cells may upregulate expression of inhibitory receptors, such as HLA-E and HLA-G, which engage inhibitor receptors on NK cells to inhibit ADCC (B). Similarly, tumor cells may express membrane bound complement regulatory proteins (mCRP), such as CD55 and CD46, which act to inhibit cleavage of $\mathrm{C} 3$ by $\mathrm{C} 3$ convertase and inhibit generation of the membrane attack complex (MAC) (C). Tumor cells that express MHC I can be recognized by activated CD8+ cytotoxic T lymphocytes (CTL), which release perforin and granzyme to induce tumor cell apoptosis. However, tumor cells often downregulate expression of MHC I and display aberrant antigen processing machinery, resulting in loss of MHC I expression on the cell surface and protection from CTL mediated killing (D). The tumor microenvironment is enriched with myeloid-derived suppressor cells (MDSC) and T regulatory cells (Treg) that produce IL-10, TGF- $\beta$ and reactive oxygen species (ROS) to inhibit tumor cell killing by CTL (E). 